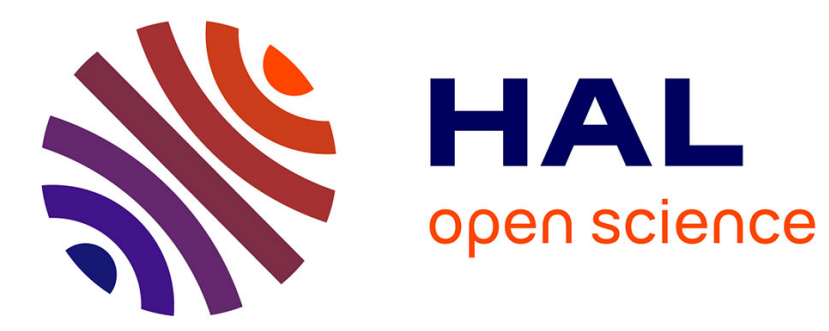

\title{
Educational and socioeconomic homogamy, development level, and metropolisation across 149 European regions
}

Milan Bouchet-Valat

\section{To cite this version:}

Milan Bouchet-Valat. Educational and socioeconomic homogamy, development level, and metropolisation across 149 European regions. Revue Europeenne des Sciences Sociales, 2018, Aménagement et urbanisme, 56 (1), pp.53-84. 10.4000/ress.3989 . hal-02081693

\section{HAL Id: hal-02081693 \\ https://hal.science/hal-02081693}

Submitted on 27 Mar 2019

HAL is a multi-disciplinary open access archive for the deposit and dissemination of scientific research documents, whether they are published or not. The documents may come from teaching and research institutions in France or abroad, or from public or private research centers.
L'archive ouverte pluridisciplinaire HAL, est destinée au dépôt et à la diffusion de documents scientifiques de niveau recherche, publiés ou non, émanant des établissements d'enseignement et de recherche français ou étrangers, des laboratoires publics ou privés. 


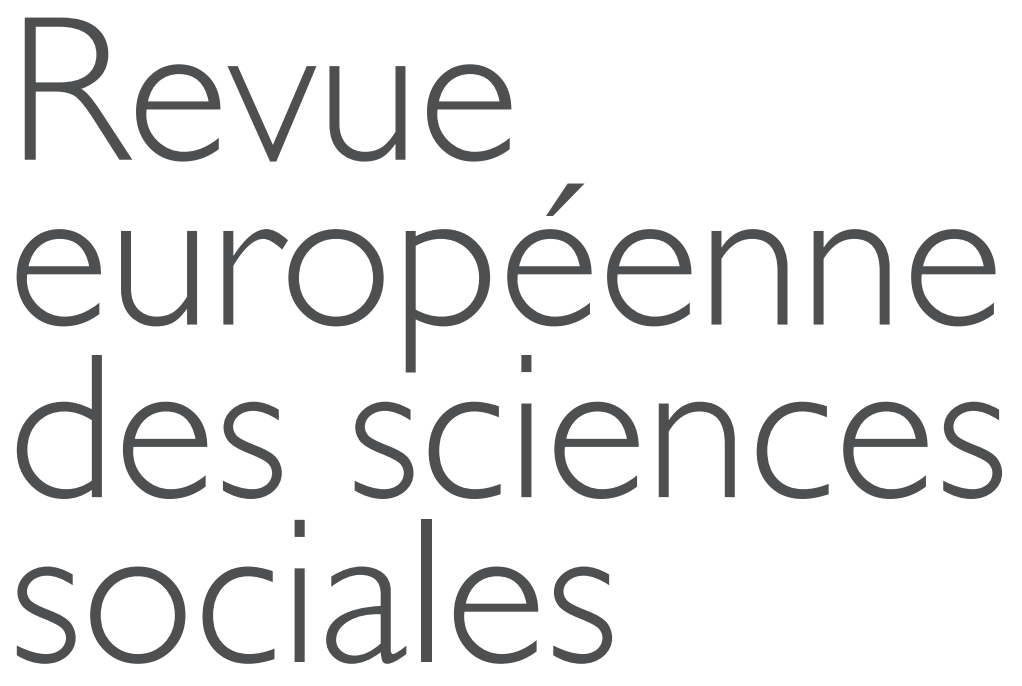

2018

European Journal of Social Sciences

\section{AMÉNAGEMENT ET URBANISME}

Dossier coordonné par

Sabine Bognon \& Élisabeth Lehec 


\section{SOMMAIRE}

VARIA

À la recherche de nouvelles traces sociales

L'exemple des conspirationnistes

Gérald Bronner, Pascal David \& Luigi Del Buono

Educational and socioeconomic homogamy, development level, and metropolisation across 149 European regions

Milan Bouchet-Valat

Comment la physique spatiale est entrée au laboratoire

La création du Centre d'étude spatiale des rayonnements (Toulouse, 1964-1970)

Jérôme Lamy

Comprendre la faible participation

des agriculteurs à la gouvernance territoriale

Étude de cas dans l'Aude

Laura Michel, Christophe-Toussaint Soulard \& Eduardo Chia

QUELLE PLACE POUR

L'AMÉNAGEMENT ET L'URBANISME DANS LES SCIENCES SOCIALES?

Présentation, par Sabine Bognon \& Élisabeth Lehec

Les recherches sur la ville en France: un champ cloisonné?

Retour sur deux exemples d'interdisciplinarité

dans la géographie urbaine des années 1970

Matthieu Pichon

Cadres théoriques et sciences humaines:

quelles leçons épistémologiques pour l'aménagement et l'urbanisme?

Céline Bonicco-Donato

L'aménagement et l'urbanisme: disciplines de l'interface, interdisciplines 203

Sabine Barles

Pour une théorie du projet en urbanisme

Nadia Arab

La bifurcation infrastructurelle

Comment compléter les théories urbaines sur les réseaux techniques urbains?

Daniel Florentin

Note critique

Olivier Galland: Pourquoi mesures objectives et représentations subjectives de l'inégalité divergent-elles?

Comptes rendus de lecture

Librairie Droz S.A.

Case postale 389

CH-1211 Genève 12

www.droz.org-droz@droz.org 
Maquette

Ingrid Allongé, Paris

Relecture \& mise en page

Ivan Jaffrin, Berlin

Caractères typographiques

Gill Sans \& Joanna, créés par Eric Gill

Édition

Librairie Droz, Genève

www.droz.org

Distribution \& diffusion

Librairie Droz, Genève

www.droz.org

ISSN : 0048-8046

(C) 2018 by Librairie Droz S.A., 11, rue Firmin-Massot, Genève.

Ce fichier électronique est un tiré à part. Il ne peut en aucun cas être modifié.

L'auteur de ce document a l'autorisation d'en diffuser ving-cinq exemplaires dans le cadre d'une utilisation personnelle ou à destination exclusive des membres (étudiants et chercheurs) de son institution. Il n'est pas permis de mettre ce PDF à disposition sur Internet, de le vendre ou de le diffuser sans autorisation écrite de l'éditeur.

Merci de contacterdroz@droz.org - http://www.droz.org. 


\title{
EDUCATIONAL AND SOCIOECONOMIC HOMOGAMY, DEVELOPMENT LEVEL, AND METROPOLISATION ACROSS I49 EUROPEAN REGIONS
}

\author{
MILAN BOUCHET-VALAT \\ Ined, Paris - CREST-LSQ \\ milan.bouchet-valat@ined.fr
}

\begin{abstract}
Considered as a key index of social stratification, social homogamy (i.e. when partners within a couple share similarities) has been used by a stream of sociological research to test theories of modernisation and industrialisation, which hold that development goes hand in hand with a weakening of both class structure and the role of kinship in the personal lives of individuals. This article investigates this issue for the first time at the sub-national scale, using data on 149 regions in 26 European countries in 2014-2016 ("European Labour Force Survey", Eurostat). I show that, whilst both educational and socioeconomic homogamy at first weaken when disposable income per inhabitant increases, they then stabilise once the European Union average income level has been reached. This relationship also holds between regions within a given country once higher levels of homogamy found in capitals and large metropolises are controlled for.
\end{abstract}

Keywords: development, homogamy, industrialisation, metropolises, modernisation, social stratification.

Résumé. Indicateur privilégié de la stratification sociale, l'homogamie sociale (soit la proximité entre conjoints) a été utilisée par un courant de recherches sociologiques pour mettre à l'épreuve les théories de la modernisation et de l'industrialisation, qui affirment que le développement s'accompagne d'un affaiblissement de la rigidité de la structure de classe et du poids de la parenté dans les destins individuels. Cet article applique pour la première fois ce questionnement à l'échelle infra-nationale à partir de données concernant 149 régions de 26 pays de l'Union européenne en 2014-2016 (« Enquête européenne sur les forces de travail », Eurostat). II montre que l'homogamie éducative et socioéconomique s'affaiblit dans un premier temps lorsque le revenu disponible par habitant augmente, mais qu'elle se stabilise une fois atteint le niveau de revenu moyen de l'Union européenne. Cette relation se retrouve entre régions d'un même pays, une fois tenu compte de la plus forte homogamie qui caractérise les capitales et les grandes métropoles.

Mots-clés: développement, homogamie, industrialisation, métropoles, modernisation, stratification sociale. 
Tiré à part adressé à Milan Bouchet-Valat

Social homogamy, the tendency of couples to unite individuals with similar social characteristics, has long been considered in the field of sociology as an essential indicator of social stratification and the openness of a given society (Lipset and Zetterberg, 1959; Ultee and Luijkx, 1990). Following in the footsteps of Max Weber and Pitirim Sorokin, many studies have sought to study the long-term evolution of societies using data on the composition of couples in terms of education and occupation. Measuring homogamy has become one way of testing theories of modernisation and industrialisation (Kerr et al., 1960, Treiman, 1970; Goode, [1964] 1982, ch. 9-10), which posit that the process of modernisation is accompanied by a weakening of rigid class structures, as well as a decline in the importance of kinship in the lives of individuals.

Building upon recent studies, this article aims to present the first international comparative study on the effect of a region's level of development on homogamy that has been conducted on a sub-national scale. I will analyse the variations in homogamy between 149 regions in 26 countries in the European Union, focusing on both the levels of education and the socioeconomic groups of the partners. I will show that there exists a negative relationship between a region's level of development and homogamy (though stabilisation is observed at the highest levels of development). This relationship persists at the sub-national level, but only becomes apparent once the presence of large metropolises in a given region has been controlled for, due to the higher levels of homogamy that characterise them.

The article begins by presenting the theoretical framework used in this study, followed by the current state of comparative studies and debates on the variations and determinants of homogamy. I will then introduce data from the "European Union Labor Force Survey" (EU-LFS), the variables used in the study, and the measurement of homogamy. After a descriptive analysis of the geographical distribution of homogamy, I will use linear regression models to explain the variations in relative homogamy among European regions, based on the average disposable income per capita and the degree of metropolisation observed. 


\section{THEORETICAL FRAMEWORK}

Falling in line with the broader framework of modernization theory, recent comparative research on homogamy has focused on two central questions: the temporal evolution of homogamy, and the directly related question of how homogamy evolves in relation to economic development.

The existing literature has sought to test the hypothesis of a two-phase evolution of homogamy depending on the stage of development reached by a given society (know as the inverted U-shaped relationship) proposed by Jeroen Smits, Wout Ultee and Jan Lammers (1998). According to these authors, in the initial "status attainment" phase, which accompanies the beginnings of industrialization, educational homogamy increases because of the increasing importance of diplomas as compared to other affiliations, and the increased role of one's education when it comes to meeting their partner. On the other hand, in the second phase, known as the "romantic love" phase, parental control over partner choice is relaxed, barriers between different social groups weaken, and individuals can afford the luxury of choosing their partners according to love due to rising standards of living, the declining economic role of the family, and the development of the welfare state. As a result, homogamy decreases during this phase. In particular, industrialization theory distinguishes two primary factors in this phase: the development of education, communications and mass media, which entails a certain degree of cultural unification; and the increase in geographical mobility and urbanisation, which helps to detach individuals from interpersonal networks that are linked to their family of origin, and increases their chances of meeting partners from different social backgrounds (Treiman, 1970, p.219).

A supplementary hypothesis, which was later added to this theory (Raymo and Xie, 2000; Smits, Ultee and Lammers, 2000), postulates that beyond a certain level of development, educational homogamy stabilises, a phenomenon which would indicate the existence of a floor towards which the most developed societies converge. 
Tiré à part adressé à Milan Bouchet-Valat

Using data from some of the most developed countries, I will attempt to test the second part of the inverted U-shaped relationship hypothesis, as well as the assumption that homogamy levels stabilise beyond a certain level of development. The choice to compare European regions is particularly suited to the assessment of this latter hypothesis, since it makes it possible to isolate the most developed regions within European countries, which correspond a priori to the situation it envisages. Conversely, the sample considered does not allow studying the first part of the inverted U-shaped relationship hypothesis, which concerns early stages of development.

Analyses at the sub-national level will allow observing closely the effect of the level of development within each country. By controlling the specific characteristics of each national context, this localized approach allows a more demanding testing of the relationship between development and homogamy than an approach that simply compares countries. Notably, this approach absorbs the differences in social structure between the countries found in the former Western and Eastern Blocs, including the consequences of the latter's transition to a capitalist system (Katrňák, Kreidl and Fónadová, 2006). Most importantly, however, this approach presents an opportunity to enrich the abovementioned theories, taking into account factors that cannot be perceived at the national level.

Indeed, at the sub-national level, the relationship between homogamy and level of development is likely to be affected, and even hidden, by the relationship between homogamy and metropolisation. Whether the chosen indicator is gross domestic product per capita or income per capita, large metropolises (especially capitals) are most often distinguished by their (sometimes dramatically) higher levels of development (Dijkstra, 2009). Thus, empirical analysis of the determinants of homogamy at the regional level must be careful not to overlook this issue.

From a theoretical point of view, this undeniable link between development and metropolisation raises a number of important questions. According to the classical theories of sociology, which can be viewed as the precursors to current theories on modernisation and industrialisation, metropolises were the centres par excellence of modernity and individualisation. According to Émile Durkheim (1997 [1893], book II. chapter 3), social control is stronger in 
small towns than in large cities, as the increase in group sizes weakens close interpersonal and familial networks. Similarly, for Georg Simmel (1950 [1903], I97 I [1908]), individuality and freedom develop in large cities because of the widening of social groups, a process that leads to increased internal differentiation. If one were to follow the logic of these hypotheses, they might expect to observe lower levels of homogamy in major cities.

In contrast, recent research suggests that city size has taken on a different meaning in European societies, which are now predominantly urban (Bagnasco and Le Galès, 2000, "Introduction"), and that the mechanisms described by classical authors no longer apply to the comparison between European regions according to their degree of metropolisation. Thus, in recent decades, urban sociology has emphasized that large metropolises are characterized by very wide gaps between social groups, which are only becoming more marked. While the aim of this paper is not to enter into the vast debate surrounding the concepts of the "world city" (Friedmann, 1986) and the "global city" (Sassen, 199I), nor the hypothesis of social polarisation, one can nonetheless note that Europe's major cities are characterized by more marked economic inequalities (Royuela, Veneri and Ramos, 2014) and socioeconomic segregation than the rest of its territories (this is especially true in the capitals, and with regard to the upper classes: see Charlot, Hilal and Schmitt, 2009; Madoré, 20I5 for France; Marcińczak, Musterd and Stępniak, 20I2; Marcińczak, Gentile and Stępniak, 2013 for Poland; Sýkora, 2009 for the Czech Republic; Burneika, Ubarevičienè and Valatka, 20I5 for Lithuania; Morgan, 1975; and Gordon and Monastiriotis, 2006 for England and Wales).

However, according to the theoretical framework most frequently used for the analysis of homogamy (Kalmijn, 1998; van Leeuwen and Maas, 2005), inequalities can influence one's choice of partner by reinforcing differences in the lifestyles and tastes of different social groups (factors which are grouped under the term "individual preferences"), while socio-spatial segregation reduces the likelihood that individuals belonging to different social groups will meet ("meeting opportunities" factor). Indeed, several studies have shown a link between homogamy and income inequality (Torche, 2010; Monaghan, 2015) as well as socio-spatial segregation (Peach, 1974; Morgan, 198I). Furthermore, 
Tiré à part adressé à Milan Bouchet-Valat

the concept of cross-cutting social circles, which was also put forth by Simmel (1964 [1908]), points to the conclusion that homogamy levels are higher in large social units (a hypothesis that is supported by empirical research, see Cheng and Xie, 2012): the number of people in each group is then sufficiently large to allow an individual to meet a partner who shares a series of characteristics that are important to him or her (whether directly or indirectly), all without exerting too much effort. The hypothesis of higher levels of homogamy in large cities must therefore be taken seriously.

Finally, it should be emphasized that most existing theoretical and empirical work has focused on educational homogamy (for an exception, see Smits, Ultee and Lammers, 1999). The socioeconomic dimension of homogamy is also very important, especially with regard to its consequences on income inequalities between households in the context of the development of female labour force participation (Schwartz, 20I3). The simultaneous study of these two dimensions of homogamy allows for the more rigorous testing of theories of modernisation, and also allows exploring the varying strengths of these dimensions according to level of development.

A total of four questions will thus be addressed. First, does homogamy weaken as level of development increases among European regions? Second, does this decline end in the most advanced stages of development and give way to stabilisation? Third, once the level of development is controlled, is homogamy stronger in regions that include large metropolises? And finally, does the effect of development vary according to whether one considers the educational or socioeconomic dimension of homogamy?

2. LITERATURE:

\section{DEBATES CENTRED ON THE INVERTED U-CURVE HYPOTHESIS}

The existing literature on variations in homogamy and their determinants in different countries has largely focused on educational homogamy—although some studies have examined social origin homogamy — and how it is affected by level of development and religion. 
International comparisons of the intensity of homogamy can be traced back to the contribution of John Hall (1954) to the collective book Social Mobility in Britain. In a short note on England, Wales, and the United States, Hall concluded that the overall level of social origin homogamy was comparable in all three societies. As homogamy and intergenerational social mobility have tended to be considered as related since Sorokin's study on the subject (1998 [1927]), the observation of this link contributed to the conclusion of Seymour Martin Lipset and Hans Zetterberg (1959), which put forth that the structures of social heredity and homogamy are broadly similar across Western countries.

As with the case of social mobility, however, this hypothesis has since been challenged by more detailed analyses. David Featherman, Frank Lancaster Jones, and Robert Hauser (1975) have advanced the more restricted hypothesis that relative mobility (i.e. mobility once changes in the structure of the population have been controlled for) in market economies and nuclear family systems is "basically identical". When applied to the question of homogamy, this weaker hypothesis is not verified either, strictly speaking.

The first to question the Lipset-Zetterberg hypothesis, Wout Ultee and Ruud Luijkx (1990) used data from 23 industrialized countries since 1945 to show significant variations in the intensity of relative homogamy and intergenerational social mobility, both between countries and over time. They noted, however, that homogamy and social heredity go hand in hand, confirming Lipset and Zetterberg's hypothesis that these two phenomena are interrelated, and can be considered indicators of a given society's general openness. The authors also showed that the level of development of a given country (measured by the number of telephone lines per inhabitant), the low level of segregation in schools (approximated by the absence of tracking before the age of I2) and a long-established presence of social democratic parties in the government, were all associated with relatively lower levels of homogamy. Contrary to what the authors expected, when these variables were controlled, the socialist countries were more homogamous than the capitalist countries observed in the study. 

AN INVERTED U-SHAPED RELATIONSHIP WITH DEVELOPMENT

This vein of research was pursued in a series of articles published by a group of researchers around Jeroen Smits. A first study (Smits, Ultee and Lammers, 1998) carried out a cross-sectional analysis of the determinants of relative educational homogamy in 65 countries, based on data from the i97os. The authors observed the aforementioned inverted U-shaped relationship between level of development (measured by energy consumption per capita and the proportion of the working population outside of the agricultural sector) and homogamy. Consistent with the theoretical framework they developed for the study, the authors found that homogamy increases during the first phase of industrialisation, then decreases. Thus, homogamy is the highest among countries in the intermediate stages of development. The study also revealed a lower tendency towards homogamy in countries whose dominant religion is Protestantism when compared to predominantly Catholic countries, countries that are both Catholic and Protestant, and countries that are predominantly Muslim or Confucian, an observation that the authors attribute to a lower emphasis on family values in predominantly Protestant countries.

The conclusion of this article regarding the higher levels of homogamy found in Confucian countries, was criticized by James M. Raymo and Yu Xie (2000) who, on the contrary, observed very similar levels of homogamy in the United States and Japan, and a lower level in Taiwan. However, the hypothesis of an inverted U-shape was partially confirmed using this new, smaller sample of countries. Most importantly, the authors emphasized the interpretive leap needed to infer a temporal trend from a cross-sectional comparison of different societies, noting that not all countries necessarily follow the same trajectory. The method of "reading history sideways" (Thornton, 200I) has already led some in the social sciences to mistakenly understand lasting differences between regions of the world as signs of an inevitable evolution towards a state considered as modern. 
In a response to this criticism, the same authors (Smits, Ultee and Lammers, 2000) enriched their previous analysis by distinguishing two birth cohorts in each country. They concluded that countries in which homogamy was statistically significantly lower among the younger cohorts outnumber those in which homogamy was statistically lower among the older cohorts (I5 versus 7) - a result that was interpreted as a sign of a gradual decline in homogamy over time. This decline appears to be even more pronounced in less developed countries, as well as those that are developing the fastest, but slows down and even reverses beyond a certain level of development. This temporal trend thus supports the hypothesis of the saturation of the increase of heterogamy past a certain point, as well as that of a resulting convergence among the most developed countries, regardless of their cultural and religious differences. Nevertheless, due to break-up and repartnering, comparing birth cohorts from a single cross-sectional survey is not a very reliable method for measuring temporal trends (Kalmijn, I99I, p.500; Bouchet-Valat, 2014, p.329). These results should thus be interpreted with a certain degree of caution.

In a continuation of previous works, Smits (2003) turned his attention to the relative endogamy of persons with completed secondary education or higher education in 55 countries. Confirming previous observations, Smits found that the endogamy of this group decreases as a given country's level of development rises, and that this decline is most pronounced when growth is high and the level of development is low. Smits also confirmed that endogamy is less marked in predominantly Protestant countries.

Finally, concluding this series of studies, Jeroen Smits and Hyunjoon Park (2009) analysed variations in educational homogamy in ten Asian countries, drawing comparisons between both countries and marriage cohorts. Confirming previous results, they observed a temporal decrease in homogamy among the successive marriage cohorts in all the countries studied, taking into account the context of rapid economic development and educational expansion. The level of development, the proportion of university graduates, and the employment rate of women appeared to be associated with low homogamy, while Confucian influence correlated with higher homogamy. 
Tiré à part adressé à Milan Bouchet-Valat

Certain limitations in these studies must be emphasized. First, one has to note the often low quality of the datasets: homogamy is measured using heterogeneous sources, and classifications are not always well harmonised. Furthermore, independent variables are often rough due to the unavailability of adequate information for all countries observed. The large sample of countries studied is at once these studies' greatest strength and primary weakness. Second, the scope of analysis is restricted to married couples, which may lead to overestimations of the strength of homogamy in countries where cohabitation is most developed, as married couples have the greatest tendency toward homogamy (Hamplová, 2009).

\subsection{RECENT STUDIES: HARMONIZED DATA}

Recent advances in both international quantitative surveys and the harmonization of national surveys have opened up the possibility of studies based on more homogeneous databases. Using data from the the "2004-2005 European Social Survey”, Henryk Domański and Dariusz Przybysz (2007) studied variations in educational homogamy across 22 European countries. This study, which had a more limited geographical scope than previous studies, observed that educational homogamy first decreases as development increases (measured as gross domestic product per capita), before rising in the more advanced levels of development, contradicting the hypothesis of the inverted U-shaped evolution for the most developed countries. It also revealed differences between groups of countries: homogamy appears to be highest in the countries of the former Soviet Bloc, and the lowest among countries with social democratic governments. Concerning the dominant religion, homogamy appears to be higher in Protestant countries. This last result, which contradicts previous studies that did not control for the welfare state regime, illustrates the difficulty of clearly separating dimensions that, in reality, are inextricably linked within national particularities.

Unfortunately, while Domański and Przybysz noted substantial variations in rates of unmarried cohabitation (up to $20 \%$ in Sweden), their study only focused on married couples. Furthermore, their analysis of the determinants of relative homogamy focused exclusively on the intensity of association among 
heterogamous couples ${ }^{1}$, thus ignoring one of the main dimensions of this phenomenon. Finally, the existence of a U-shaped relationship between level of development and homogamy, which was estimated using a linear regression model with gross domestic product per capita and its square as independent variables, was not accompanied with details that would have allowed for the evaluation of the goodness of fit and significance of the curve.

Tomáš Katrňák, Petr Fučík and Ruud Luijkx (20I2) also used the "European Social Survey" (2002, 2004, and 2006) to study the link between educational homogamy, intergenerational mobility in terms of education, and educational inequalities in 29 European countries. They concluded that there is a strong correlation (between 0.8 and o.9) between the intensity of educational homogamy and of educational heredity in relative terms (i.e. the inverse of relative social mobility), a sign that both dimensions can be considered as an index of the same phenomenon: social openness. However, homogamy was found to be systematically higher than intergenerational immobility, and thus constitutes a better indicator of the degree of openness of a society from the point of view of education. The study also confirmed the results of the previous study (Domański and Przybysz, 2007) according to which relative educational homogamy is the highest in the countries of the former Soviet Bloc, and the lowest in Scandinavian countries, France, and Great Britain ${ }^{2}$. It should be noted that once again, only married couples were considered in this study.

Despite their considerable differences, one can attempt to summarize these various studies by highlighting a few salient points. Firstly, the hypothesis that homogamy does not vary between developed countries has clearly been rejected. As with intergenerational social mobility, with which homogamy appears to be closely linked, significant differences can be observed even after the structure of the population has been controlled for. However, the link between homogamy

I Specifically, the modelling was based on the step parameter of a distance model with country-specific diagonal parameters.

2 However, there are some notable differences, such as the very low homogamy of Estonia and Norway, which were on the contrary among the most homogamous countries in the previous study. Given the results obtained below, this strong homogamy seems to be an artefact linked to the specification of the model used. 
Tiré à part adressé à Milan Bouchet-Valat

and the level of development remains debated, particularly in the case of Europe. The study carried out by Domański and Przybysz (2007), which concludes that homogamy is reinforced at the highest levels of development, seems to be the exception, and necessitates further study to confirm this conclusion.

\section{GEOGRAPHICAL SCOPE, DATA AND METHOD}

When compared to the broader studies that have been cited, the geographical scope of this study presents both advantages and limitations. The latter are due to the relative homogeneity, on both a geographical and historical scale, of contemporary European societies: the variety of their social structures and levels of development is relatively narrow, which makes it difficult to test general theories like modernization theory. Thus, the following analyses can only address the determinants of homogamy at an advanced stage of modernisation. These remarks should not, however, lead one to underestimate the extent of the differences between countries (and, to an even greater extent, regions) of the European Union, which are sufficient to study the determinants of partner choice. Social structures remain strongly contrasted between East and West, as well as between North and South (Breen, 2004; Róbert, 2010). Family patterns, including the conditions of leaving parental home and of first couple formation, also vary widely, in part due to these East-West and North-South oppositions (Reher, 1998; Billari, Philipov and Baizán, 200I; Sobotka and Toulemon, 2008; Puur et al., 20I2).

Conversely, the benefits of an analysis limited to Europe are manifold. On a theoretical level, homogeneity is also an asset (Smits and Park, 2009, p.229), insofar as it ensures a certain level of equivalence, the validity of which would be difficult to determine in the context of a comparison of countries with drastically different levels of development. On a practical level, rich and highquality data are available at the European scale, allowing for the description of regional differences within each country as a means of evaluating their homogeneity and of increasing variations between units of analysis. To my knowledge, this is the first time that a comparative study of homogamy has descended to the sub-national scale, and touched upon both the educational and socioeconomic dimensions of partner choice. 


\section{I. GEOGRAPHICAL UNITS: THE NUTSI AND NUTS2 REGIONS}

The study is based on the 2014, 2015 and 2016 waves of the "European Union Labor Force Survey" (EU-LFS), which consists in a compilation by the European statistical office Eurostat of the labour force surveys carried out at the national level in each of the member states of the European Union. 26 countries $^{3}$, divided into I49 regions, were selected: Austria (AT), Belgium (BE), Bulgaria (BG), Cyprus (CY), Croatia (HR), Estonia (EE), France (FR), Germany (DE), Greece (GR), Hungary (HU), Ireland (IE), Italy (IT), Latvia (LV), Lithuania (LT), Luxembourg (LU), Norway (NO), the Netherlands (NL), Poland (PO), Romania (RO), Slovakia (SK), Slovenia (SI), Spain (ES), Sweden (SE), and the United Kingdom (UK).

The elementary scale of analysis is the NUTS 1 or NUTS2 regions (Nomenclature of Territorial Units for Statistics). The NUTS I regions are comprised of between 3 and 7 million people, and the NUTS2 regions between 800,000 and 3 million people. The choice of retaining one level rather than the other was made based on the availability of information concerning the NUTS2 regions, and the size of the available samples for each region: in the end, the NUTS I level was used for Germany, Bulgaria, Spain, France, Greece, the Netherlands and the United Kingdom4 ${ }^{4}$. Regional samples consist of I,000 to 55,000 observations, and three quarters of the samples consist of more than 3,000 observations. All analyses are weighted according to the population size of each region.

3 Norway, although not a member of the European Union, participates in the "European Labour Force Survey" as an associated country. Moreover, it is impossible to identify couples in national surveys which are not conducted at household level. For this reason, Denmark and Finland could not be included in the sample, and Luxembourg was excluded for the year 20I4. Finally, Malta had to be excluded due to the lack of precision of the coding of occupation.

4 In addition, the city of Prague (CZOI) was merged with the surrounding region (CZO2), and northern Sweden was regrouped at the NUTSI (SE3) level. 


\subsection{Level of education}

The partners' educational levels are measured using four categories: lower secondary or less (ISCED o-2, including short vocational education); upper secondary (ISCED 3); lower tertiary (ISCED 4-6: up to and including Bachelor's); upper tertiary (ISCED 7-8: Master's and beyond). Regrettably, it is impossible to use a more detailed classification system. In spite of efforts made by UNESCO, the OECD, and Eurostat to harmonise the definition and implementation of the International Standard Classification of Education (ISCED-20II), the "European Labour Force Survey's" codification of nationally-recognised diplomas remains very flawed. Thus, while the data provided by Eurostat could potentially distinguish 12 categories (revising and refining those proposed by ISCED), many are only used by a handful of countries (see Schneider and Kogan, 2008, p.34-42; and Schneider, 2009, section 4.I.3 on the implementation of the previous version of the classification).

However, the impact of this problem on the measurement of variations in the intensity of homogamy in different European regions should not be overestimated: results appear relatively robust to changes in nomenclature. Falling in line with the observations of Smits, Ultee and Lammers (1998, n. 4), I find that the correlation between the indices of the intensity of relative homogamy in the different countries and regions obtained using more or less detailed classifications is greater than 0.85 . Moreover, the fact that the classification distinguishes two levels of higher education protects against the risk of underestimating the level of homogamy of regions, which have experienced the strongest educational expansion ${ }^{5}$.

5 Indeed, differences in the intensity of homogamy between regions situated at the two extremes of level of development appear to be higher when this distinction is not made. 


\subsubsection{Socioeconomic group}

The socioeconomic position of each partner is measured using the recent European socioeconomic classification, ESeG (European Socio-Economic Groups, see Meron and Amar, 20I4). The ESeG scheme comprises seven categories: managers (both employees and owners of large companies); professionals; technicians and associated professionals employees; small entrepreneurs (self-employed with or without employees, including farmers); clerks and skilled service employees; industrial skilled employees; and less skilled employees.

In order to limit the influence of differences in female employment rates between regions, the socioeconomic group of unemployed respondents is defined according to their last job. This information is only available when the person in question has been employed at some point in the eight years prior to the survey. The results obtained using only couples in which both partners are employed are almost identical to those obtained for the full sample (with a correlation of variations in intensity of relative homogamy of 0.92).

\subsubsection{Level of development}

The level of development is measured by the disposable income per capita in purchasing power parity at the regional level, as calculated by Eurostat. For data availability reasons, I chose to focus on the year 2006, in an effort to get closer to the average date at which the observed couples formed ${ }^{6}$.

The choice to use disposable income rather than gross domestic product can be justified by the fact that richer regions (including capitals) generally have a much higher gross domestic product than disposable income due to the redistribution of income between regions, as well as the domiciliation of business headquarters. Regardless of the mechanism linking economic development to partner choice, it is thought that it depends more on the concrete living conditions of individuals than on a purely accounting measure of wealth? This interpretation is empirically

6 Very similar results can be obtained by retaining other reference points between the years 2000 and 2011 .

7 However, it should be noted disposable income does not take in-kind transfers through public services into account. 
Tiré à part adressé à Milan Bouchet-Valat

confirmed by the fact that the correlation between development and homogamy is much higher when disposable income is used instead of gross domestic product.

\subsubsection{Metropolises}

Regions with metropolises were identified using the classification system established by Lewis Dijkstra (2009), which includes three levels of metropolisation: regions containing a capital, regions with a "second-tier metropolis", and other regions that only contain "small metropolises". Due to the lack of precision of the NUTS I and NUTS2 regions selected for this analysis, I had to allow for some exceptions in order to avoid retaining nearly the entire territories of certain countries. In the United Kingdom, only the largest cities were chosen along with London: Manchester and Liverpool (both in the same region), Birmingham, Leeds-Bradford and Sheffield (also in the same region). In Croatia, Romania and Slovenia, no metropolises were chosen, aside from each country's capital. Countries made up of a single region could not, by definition, be placed in one of these three categories. Overall, excluding singleregion countries, the sample includes 20 regions with one capital city, and 36 regions with one or more metropolitan areas.

This method of identifying the effect of metropolisation is, of course, far from perfect. While it works well for large capitals that are isolated within an administrative region $^{8}$, it is too coarse for some capitals and for most second-tier metropolises, which are sometimes integrated into large regions comprising mediumsized towns and rural areas. Therefore, the results obtained using this classification correspond to a low estimate of the differences between large metropolises and small towns, and need to be refined using data obtained on a finer scale.

8 This is the case for London, Paris, Madrid, Berlin, Athens, Brussels, Lisbon, Prague, Bucharest, Stockholm and Bratislava. 


\subsection{SCOPE: COHABITING COUPLES}

All cohabiting couples, regardless of whether or not they are married, were retained for the study. Several couples could be identified within a single household. The proportion of households containing several couples is very low in most regions, but exceeds $5 \%$ (sometimes even approaching $10 \%$ ) in certain regions of Bulgaria, Croatia, Poland, Romania and Slovakia.

The analysis is restricted to couples in which both partners are between the ages of 30 and 59, so as to limit on one hand the influence of changes in marriage age, and on the other, the proportion of retirees for whom employment information would be missing. The final sample consists of I,400,000 couples for educational homogamy, and I,100,000 couples for socioeconomic homogamy. Finally, it should be noted that the modelling is based on weighted tables: each region is represented in proportion to its population in the European Union.

\subsection{MEASURING RELATIVE HOMOGAMY}

The sociological literature on homogamy generally favours the measurement of relative homogamy, as opposed to using an absolute measurement represented by the proportion of couples in which partners belong to the same educational or socioeconomic group (homogamy rate). Relative homogamy, which is measured using odds ratios, is defined in relation to a reference situation in which individuals would choose their partners at random. This method of measurement has the useful property that it does not depend on the educational or socioeconomic structure of each region. Thus, relative homogamy makes it possible to more directly approach the processes that bring together or separate social groups, and allows for reliable comparisons between regions with radically different social structures.

Since I am interested in the overall intensity of homogamy in each region, I do not use log-linear modelling, which is frequently used in the existing literature, but whose main interest is to reveal the structure of homogamy, rather than its overall level. I compute a simpler non-parametric index of the intensity of homogamy, using the set of odds ratios from the homogamy tables computed for each region: the intrinsic association coefficient (Goodman, 1985, 1996), which ranges from o (no 
Tiré à part adressé à Milan Bouchet-Valat

homogamy, a situation equivalent to random mating) to infinity (maximum possible homogamy given the structure of the population) ${ }^{9}$. In order to give each odds ratio an importance that is proportional to the size of the social groups to which it corresponds in the European Union, a weights equal to the average of the margins is used.

After a descriptive analysis of the value of this index for each region, the following section will test the abovementioned hypotheses, using a linear regression to model the value of the index.

\section{RESULTS}

\section{I. THE GEOGRAPHY OF RELATIVE HOMOGAMY IN EUROPE}

When laid out on a map, the representation of intrinsic association coefficients measuring the intensity of educational and socioeconomic homogamy reveals significant differences between regions (see Figure I). Two general observations can be made.

First, there is a moderately high correlation (with a coefficient of 0.45 ) between the educational and socioeconomic dimensions of relative homogamy. Therefore, it seems that the two indicators used here partly cover the same phenomenon, but also diverge considerably.

Second, educational homogamy is by far the strongest dimension of homogamy: the weighted average of regional intrinsic association coefficients ${ }^{10}$ is equal to 0.72 for education, versus 0.57 for socioeconomic group. Moreover, educational homogamy is higher than socioeconomic homogamy in 120 out of 149 regions. The intrinsic association coefficient measuring the intensity of educational homogamy

9 This index is equal to the Altham index (Altham and Ferrie, 2007) up to a factor taking into account the dimensions of the table, which is appropriate since educational homogamy and socioeconomic homogamy are not measured using the same number of categories. Tables and code to reproduce the results are available on the author's personal webpage at $<$ http://bouchet-valat.site.ined.fr> or upon request.

I0 It should be noted that contrary to its absolute version, this relative measure of the intensity of homogamy does not increase mechanically when a more aggregated classification is used (as in the case of education). Nevertheless, any measurement remains dependent on the classification used: these comparisons should not be considered as perfectly accurate, but rather as indications of a trend. 
Tiré à part adressé à Milan Bouchet-Valat exceeds 0.85 in one third of the regions (with a record of $\mathrm{I} .5$ in Slovakia), a level that is reached by only one region (in Romania) with regard to socioeconomic homogamy. However, socioeconomic homogamy is higher than educational homogamy in many parts of Western Europe, where educational homogamy is relatively low, while levels of socioeconomic homogamy are fairly average. This is the case in certain regions of Spain, Portugal, Italy, Belgium and Luxembourg. At first glance, then, it seems that educational homogamy declines more clearly with development than socioeconomic homogamy, which is generally weaker.

Figure I. Geographical Distribution of Educational and Socioeconomic Homogamy in Europe

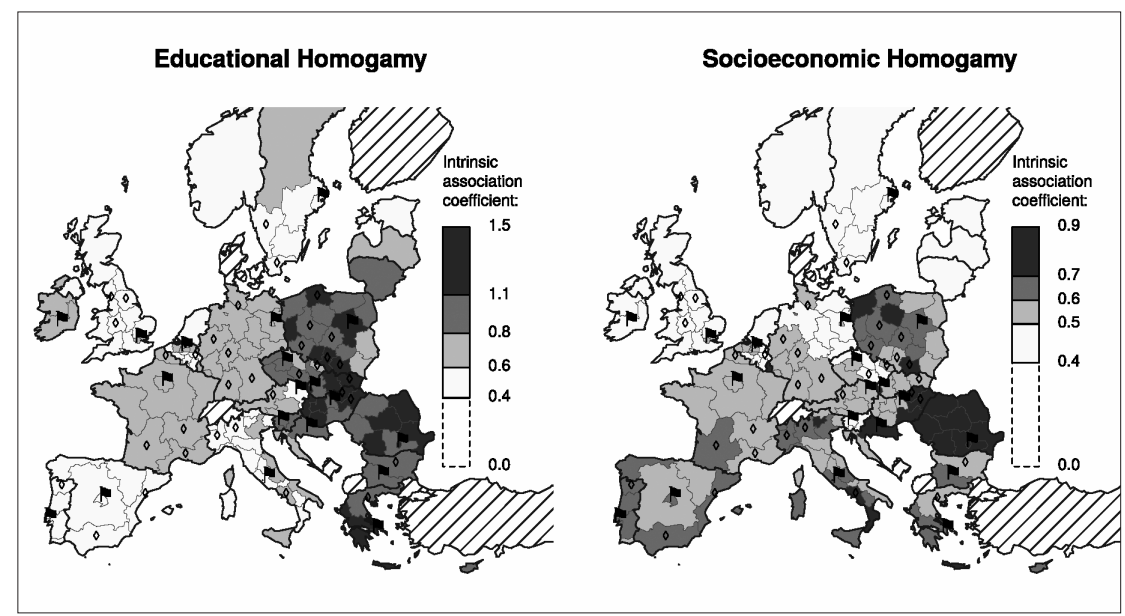

Source: "European Labour Force Survey", 2014-2016 (Eurostat)

Scope: Cohabiting couples aged 30 to 59 (in which both partners worked at some point during the eight years preceding the survey for the socioeconomic group)

The division into different classes was automatically performed using the Jenks algorithm (1967).

Regions marked with a "N" include a capital, and those marked with a " $\checkmark$ " include a second-tier metropolis.

The geographical distribution of educational homogamy is fairly clear-cut, with high levels of homogamy in the East" ${ }^{11}$ and lower levels towards the north and west. Educational homogamy is thus very strong in the former "people's democracies", with high levels observed in Slovakia, Romania, Hungary, Poland, Bulgaria, and to a

II A finer representation of the differences within Germany reveals greater educational homogamy in former East Germany. 
Tiré à part adressé à Milan Bouchet-Valat

lesser extent Slovenia, Croatia, Czech Republic and Lithuania. With a few exceptions (notably Greece, Latvia and Estonia), this eastern belt, which extends from North to South, closely corresponds to the boundaries of the former Eastern Bloc. Conversely, educational homogamy is low in the West and North of the continent, but it is somewhat higher in Ireland, France, Germany, Austria and parts of Italy than in the rest of Northern and Western Europe. The clear opposition between the high levels of educational homogamy in Central and Eastern Europe, and the lower levels of educational homogamy in Western and Northern Europe, supports the results of previous studies (Domański and Przybysz, 2007; Katrňák, Fučík and Luijkx, 20I2).

The distribution of socioeconomic homogamy is less distinct. Apart from Romania, which is clearly distinguished by its high levels of homogamy, we can also find relatively strong homogamy in some regions of Poland, Slovakia, Hungary, Croatia, Greece, Italy and Luxembourg. Conversely, socioeconomic homogamy is very low in many countries found further north, including Ireland, the United Kingdom, the Netherlands, northern Germany, Norway, Sweden, Lithuania, Latvia and Estonia. The countries belonging to the first group are all characterized by a strong influence of either the Catholic (as in the majority of these countries) or the Orthodox (as is the case in Romania and Greece) Churches. The second group, on the other hand, includes regions with long Protestant traditions (with the notable exceptions of Ireland and Lithuania). This confirms the results of Smits, Ultee and Lammers (1998) at the regional level in Europe.

Overall, educational and socioeconomic homogamy appears to be more prevalent in the less-developed regions in the East of the continent. However, the determinants of these two dimensions seem to differ to a certain extent, with a country's political system (and, by extension, educational system) having more influence on educational homogamy, and religion having more influence on socioeconomic homogamy. 


\subsection{A DECREASE IN HOMOGAMY AS DEVELOPMENT LEVELS RISE}

The higher geographic regularity of socioeconomic homogamy compared with educational homogamy is again visible when considering the relationship between homogamy and disposable income per capita, taken as an indicator of the level of development of a given region. Figure 2 shows the distribution of the studied regions according to these two variables. Disposable income per capita is presented in standardized form: o corresponds to the average income of the regions, and I represents a standard deviation. The regions range from about two standard deviations below the average (from $€_{3,500}$ to $€_{4,500}$ in Romania and Bulgaria) to two standard deviations above the average ( $€ 22,000$ in Luxembourg and $€_{25,000}$ in London).

Figure 2. Educational and socioeconomic homogamy in the regions of Europe by disposable income per capita

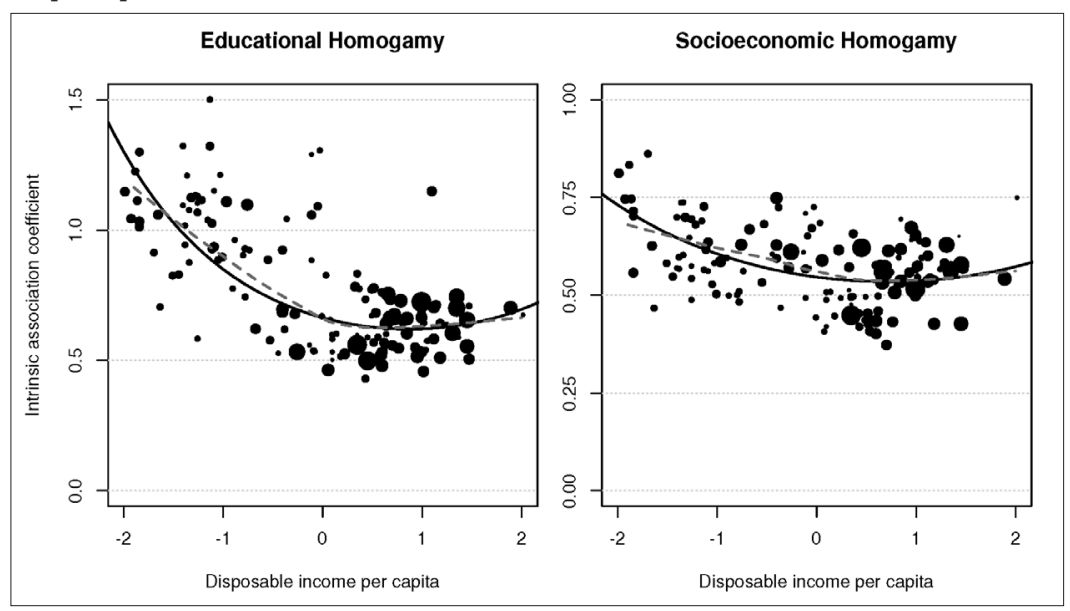

Source: "European Labor Force Survey 2014-2016" (Eurostat)

Scope: Cohabiting couples aged 30 to 59 (in which both spouses worked at some point during the eight years preceding the survey for the socioeconomic group)

Disposable income is normalized (with the average equal to 0 and standard deviation equal to 1 ).

The continuous curve represents the parabola obtained by estimating a regression model of homogamy on disposable income per capita and its square. The dotted curve represents the non-parametric smoothing obtained using a local regression of degree I (LOESS).

The area of the discs is proportional to the population of the corresponding regions. 
Tiré à part adressé à Milan Bouchet-Valat

The black curve indicates the relationship estimated by a linear regression model, the dependent variable being the intensity of homogamy (logarithm of the intrinsic association coefficient ${ }^{12}$ ), and the independent variables being disposable income per capita and its square (see Table I). This simple model alone explains $48 \%$ of the variance of educational homogamy, but only $22 \%$ of the variance of socioeconomic homogamy, confirming that the former varies more clearly according to level of development than the latter. According to this model, moving from a per-capita income that is two standard deviations below the average (approximately the level of the least developed regions in the study) to the average income level reduces educational homogamy by $48 \%{ }^{13}$ and socioeconomic homogamy by $25 \%$. Similarly, rising from an average income to an income level that is two standard deviations above the average (approximately the level of the most developed regions in the study) increases educational homogamy by $4 \%{ }^{14}$, and decreases socioeconomic homogamy by $5 \%$ (that is to say, quasi-stability).

Thus, we observe, on the one hand, a clear decrease in homogamy as a region's development level rises and, on the other hand, a stabilisation once disposable income per capita has exceeded the European average. These observations therefore support my first two hypotheses. However, we do not observe a trend reversal, which would indicate a U-shaped relationship with an increasing homogamy at the highest levels of development. Finally, development has much more of a negative effect on educational homogamy than it does on socioeconomic homogamy; both dimensions can be found at approximately the same level in the regions with around and above the average level of development in Europe.

12 The logarithm is used so that the independent variables have a multiplicative rather than an additive effect: indeed, increasing or decreasing homogamy by a certain factor makes more sense than adding or subtracting a certain quantity. Furthermore, this operation gives a more symmetrical distribution.

13 Or $1 /\left(0.86^{-2} \times 1.09^{4}\right)-1$. Unless otherwise specified, all of the effects mentioned are significant at the $5 \%$ level (see Table I).

14 Or $0.86^{2} \times 1.09^{4}-1$. 


\subsection{HOMOGAMY, DEVELOPMENT AND METROPOLISATION AT THE SUB-NATIONAL LEVEL}

The level of detail of the data makes it possible to refine these results by studying the relationship between homogamy and disposable income per capita between regions in the same country. This second approach makes it possible to control all the national particularities that may interfere with the identification of the effects of a given country's level of development. In particular, one may consider the institutional framework ${ }^{15}$ governing a given country's educational system and labour market, as it is likely to influence partner choice, if only by affecting the extent of contacts between groups (for example in the context of schooling).

These national particularities are controlled using a model containing dummy variables identifying the regions belonging to each of the 26 countries included in the study (country fixed effects). The coefficients associated with the model's independent variables thus measure their effect on the intensity of homogamy after controlling for country. It should above all be noted that the indicator variables controlling for country explain $90 \%$ of the variance of educational homogamy and $78 \%$ of the variance of socioeconomic homogamy (after excluding the seven countries that are made up of a single region): most differences in levels of homogamy between regions of Europe are in fact due to differences between countries.

The remaining variations, which correspond to sub-national differences, are not very well explained by level of development alone: model 2, which in addition to country fixed effects, includes disposable income per capita (and its square), explains $3 \%$ of variations in educational homogamy and i $\%$ of variations in socioeconomic homogamy (within-country $\mathrm{R}^{2}$, see Table I). Although the coefficients associated with disposable income remain less than I, indicating a negative effect of development on homogamy, their strength is considerably weakened, and they are not statistically significant.

15 While this framework can vary between regions in the same country, taking the national context into account nevertheless allows controlling a large share of variations between European regions in that regard. 
Milan Bouchet-Valat: Educational and socioeconomic homogamy...

Tiré à part adressé à Milan Bouchet-Valat

Table I. Regressions explaining educational and socioeconomic homogamy by disposable income per capita and the presence of a capital or metropolis

\begin{tabular}{|c|c|c|c|c|c|c|c|c|}
\hline & \multicolumn{4}{|c|}{ EDUCATIONAL HOMOGAMY } & \multicolumn{4}{|c|}{ SOCIOECONOMIC HOMOGAMY } \\
\hline & MI & M2 & M3 & M4 & MI & M2 & M3 & M4 \\
\hline \multirow{2}{*}{$\begin{array}{l}\text { Disposable } \\
\text { Income }\end{array}$} & 0.86 & 0.96 & & 0.92 & 0.94 & 0.98 & & 0.94 \\
\hline & $(0.83 ; 0.88)$ & $(0.89 ; 1.03)$ & & $(0.85 ; 0.99)$ & $(0.92 ; 0.96)$ & $(0.93 ; 1.04)$ & & $(0.89 ; 0.99)$ \\
\hline \multirow{2}{*}{$\begin{array}{l}\text { Disposable } \\
\text { Income }^{2}\end{array}$} & 1.09 & 1.02 & & 1.03 & 1.04 & 1.04 & & 1.05 \\
\hline & $(1.06 ; 1.13)$ & $(0.96 ; 1.10)$ & & $(0.97 ; 1.10)$ & $(1.02 ; 1.07)$ & $(1.01 ; 1.08)$ & & $(1.02 ; 1.09)$ \\
\hline $\begin{array}{l}\text { Other } \\
\text { Region (Ref.) }\end{array}$ & & & 1.00 & 1.00 & & & 1.00 & 1.00 \\
\hline \multirow{2}{*}{ Capital } & & & 1.04 & 1.08 & & & 1.08 & 1.10 \\
\hline & & & $(0.96 ; 1.12)$ & $(0.99 ; 1.18)$ & & & $(1.02 ; 1.14)$ & $(1.04 ; 1.16)$ \\
\hline \multirow{2}{*}{ Metropolis } & & & 1.00 & 1.01 & & & 1.04 & 1.04 \\
\hline & & & $(0.97 ; 1.04)$ & $(0.97 ; 1.04)$ & & & $(1.00 ; 1.07)$ & $(1.01 ; 1.07)$ \\
\hline \multirow{2}{*}{ Intercept } & 0.66 & 0.65 & 0.62 & 0.65 & 0.55 & 0.54 & 0.53 & 0.53 \\
\hline & $(0.64 ; 0.69)$ & $(0.59 ; 0.70)$ & $(0.59 ; 0.66)$ & $(0.59 ; 0.7 I)$ & $(0.53 ; 0.57)$ & $(0.50 ; 0.57)$ & $(0.51 ; 0.55)$ & $(0.50 ; 0.56)$ \\
\hline $\begin{array}{l}\text { Country } \\
\text { fixed effects }\end{array}$ & & $x$ & $x$ & $x$ & & $x$ & $x$ & $x$ \\
\hline Observations & 146 & 146 & 146 & 146 & 146 & 146 & 146 & 146 \\
\hline $\mathrm{R}^{2}$ & 0.48 & 0.90 & 0.90 & 0.91 & 0.22 & 0.83 & 0.83 & 0.85 \\
\hline Adjusted $\mathrm{R}^{2}$ & 0.47 & 0.88 & 0.88 & 0.89 & 0.21 & 0.79 & 0.79 & 0.82 \\
\hline $\begin{array}{l}\text { Within } \\
\text { country } \mathrm{R}^{2}\end{array}$ & 0.00 & 0.02 & 0.02 & 0.09 & 0.00 & 0.11 & 0.14 & 0.25 \\
\hline
\end{tabular}

Relative homogamy is measured by the logarithm of the intrinsic association coefficient: the effect is therefore multiplicative. Disposable income is normalized (with an average equal to 0 , and a standard deviation equal to I). Each region is weighted according to the size of its population. $95 \%$ confidence intervals obtained via normal bootstrap on the regions ${ }^{16}$ (selected from within each country) are reported in parentheses.

Source: "European Labor Force Survey 2014-2015" (Eurostat)

Scope: Cohabiting couples aged 30 to 59 (in which both partners worked at some point during the eight years preceding the survey for the socioeconomic group)

Read:After taking variations between countries and per capita income into account, relative educational homogamy is $8 \%$ higher in regions with a capital, compared to regions without a capital or large metropolis (see Model 4).

I6 These confidence intervals, which reflect the uncertainty of the generalisation from this study's sample of regions to a wider geographical scope, constitute a rather demanding test of the robustness of the results. The intervals measuring the uncertainty associated with the fact that the level of homogamy of each region is estimated using a sample of individuals (without focusing on generalisation beyond the regions studied) are much narrower.

Ce PDF ne peut être ni vendu ni diffusé sur Internet. (c) Librairie Droz S.A. 
This apparent absence of a link is, however, misleading: it may be due to the fact that regions containing a large metropolis, and even more so those with a capital, have both relatively high levels of homogamy and relatively high incomes when compared to other regions within the same country. This is illustrated in Figure I, where capitals are indicated by a flag: although capitals are usually the most developed cities, they often belong to the most homogamous regions of their country. This phenomenon is particularly evident in several capitals whose metropolitan area corresponds closely to the borders of a region, including London, Madrid, Berlin, Brussels, Bucharest, Prague and Bratislava (with some exceptions, depending on the dimension under consideration).

In order to more rigorously confirm this observation, I introduce in the models a variable indicating the presence of a capital or a metropolis in a region, in addition to the fixed effects controlling the level of homogamy specific to a given country. The addition of this variable to a model with only country fixed effects only slightly improves the description of the data (see Table I, Model 3): the share of within-country variations that are explained by the model (within-country $\mathrm{R}^{2}$ ) is $2 \%$ for educational homogamy and $14 \%$ for socioeconomic homogamy.

On the other hand, the simultaneous control of income per capita (and its square) and of metropolisation (see Model 4) reveals more discernible effects, with the share of intra-country variance explained by the model increasing to $9 \%$ for educational homogamy and to $25 \%$ for socioeconomic homogamy. Thus, with controlling for country and metropolisation, moving from an income that is two standard deviations below the average to an average income decreases educational homogamy by $25 \%$ and socioeconomic homogamy by $27 \%$. Moving from an average income to one that is two standard deviations above the average income decreases educational homogamy by $5 \%$ and increases socioeconomic homogamy by $7 \%$. In regions with a capital, educational homogamy is $8 \%$ higher and socioeconomic homogamy is $10 \%$ higher than in regions without a capital or metropolis. Regions with a second-tier metropolis also appear to be relatively more homogamous than other regions in socioeconomic terms. 
Tiré à part adressé à Milan Bouchet-Valat

We can thus observe that the higher levels of homogamy observed in capitals partly overshadow the negative correlation between development and homogamy, which persists at the sub-national level (though less markedly than without controlling for country in the case of educational homogamy). The phenomenon of stabilisation at the highest levels of development can also be confirmed at this geographic scale, at least as far as socioeconomic homogamy is concerned ${ }^{17}$. Once again, no evidence of the reinforcement of homogamy at the most advanced stages of development can be observed.

\section{CONCLUSION}

The aim of this study was to test three hypotheses concerning the relationship between development level and homogamy: first, that of a weakening of homogamy as development advances; secondly, that of the stabilisation of homogamy at the most advanced stages of development; and lastly, that of a higher level of homogamy in metropolises once the level of development is controlled. Results support all three hypotheses. They are valid for both educational homogamy and socioeconomic homogamy, although the effects of development are stronger with regard to the former.

Observing the geographical distribution of homogamy in Europe has revealed that it is far more pronounced in educational terms than in socioeconomic terms. Educational homogamy is higher in the eastern part of the continent (notably in a strip of countries stretching from Lithuania to Greece), and largely overlaps with more general oppositions between the former Eastern and Western Blocs, with some exceptions. Socioeconomic homogamy, on the other hand, appears to be higher in the East and South of the continent, particularly in regions whose common feature is a strong influence of the Catholic or the Orthodox Churches. Conversely, the regions of Northern Europe, which are mostly Protestant, are characterized by lower levels of socioeconomic homogamy.

17 The coefficient associated with income squared is not statistically significant for educational homogamy. 
This geographical distribution also corresponds to differences in levels of development, the analysis of which was systematized in a second step using the average per capita disposable income of each region. The most developed regions in Europe are characterized by a level of educational homogamy two to three times lower, and by a level of socioeconomic homogamy about two times lower, than that of the less-developed regions. The negative effect of development on homogamy is very strong below the European average, but diminishes and disappears completely once it rises above the average, a phenomenon that supports the hypothesis regarding saturation beyond a certain level of development.

The negative relationship between development and homogamy persists (albeit to a lesser extent for educational homogamy), at the sub-national level, when the average intensity of homogamy in each country (country fixed effects) and the presence of a capital or second-tier metropolis in each region are controlled for. Regions containing a capital are characterized by a homogamy level that is nearly $10 \%$ higher than that found in regions with a similar level of development, but no metropolis.

Generally speaking, these observations confirm the prediction put forth by the theory of modernisation, as well as the conclusions of previous comparative studies: that homogamy decreases at the highest levels of development (Smits, Ultee and Lammers, 1998, 2000; Raymo and Xie, 2000; Smits, 2003; Smits and Park, 2009). However, the hypothesis of an increase in homogamy beyond a certain point of development (Domański and Przybysz, 2007) is rejected by my data. While some of the most developed regions of Europe have higher levels of homogamy than their neighbours, it is due to the presence of metropolises, and not because of their high levels of development.

These conclusions call for additional research in at least two directions. First, as it would be risky to infer temporal changes from a correlation between characteristics of societies at a given moment (Thornton, 200I; Raymo and Xie, 2000), it is necessary to combine spatial comparison with a temporal comparison in order to confirm that the relationship between homogamy and development observed in this study clearly reflects the historical trajectories followed by European societies. Existing studies have not yet succeeded in identifying any regularities 
Tiré à part adressé à Milan Bouchet-Valat

in the temporal evolution of homogamy in Europe (Bouchet-Valat, 20I4). Second, a better understanding of the mechanisms linking development and homogamy can only be achieved through the mobilisation of more detailed indicators than per capita income. By increasing the number of independent units studied, and the extent of variations between them, sub-national analysis can go beyond what national studies have been able to observe thus far. A finer-grained approach would also help to account for the factors underlying the highest levels of homogamy in metropolises, as well as the predominance of educational homogamy over socioeconomic homogamy.

\section{BIBLIOGRAPHY}

ALTHAM P.M.E. and FERRIE J.P., 2007, "Comparing Contingency Tables Tools for Analyzing Data from Two Groups Cross-Classified by Two Characteristics", Historical Methods, 40-I, p.3-16.

BAGNASCO, A. and LE GALÈS P. (eds.), 2000, Cities in Contemporary Europe, Cambridge, Cambridge University Press.

BILLARI F.C., PHILIPOV D. and BAIZÁN P., 200I, "Leaving Home in Europe: The Experience of Cohorts Born Around 1960", International Journal of Population Geography, 7-5, p.339-356.

BOUCHET-VALAT M., 2014, "Changes in Educational, Social Class and Social Class of Origin Homogamy in France (1969-201I): Greater Openness Overall But Increased Closure of Elites", Revue française de sociologie, 55-3, p.324-364.

BREEN R. (ed.), 2004, Social Mobility in Europe, Oxford, Oxford University Press.

BURNEIKA D., UBAREVIČIENĖ R. and VALATKA V., 20I5, "Socio-Economic Segregation in Growing Urban Regions of Lithuania", Filosofija. Sociologija, 4, p.277-292.

CHARLOT S., HILAL M. and SCHMITT B., 2009, "La périurbanisation renforce-t-elle la ségrégation résidentielle urbaine en France?", Espace populations sociétés, I, p.29-44.

CHENG S. and XIE Y., 20I2, "Size Matters: The Structural Effect on Social Relations", Population Studies Center Research Report, 12-756, Chicago, University of Michigan. 
Revue européenne des sciences sociales

Tiré à part adressé à Milan Bouchet-Valat

DIJKSTRA L., 2009, "Metropolitan regions in the EU”, Regional Focus, 01/2009, European Union Regional Policy.

DOMAŃSKI H. and PRZYBYSZ D., 2007, "Educational Homogamy in 22 European Countries", European Societies, 9-4, p.495-526.

DURKHEIM É., 1997 (1893), The Division of Labour in Society, New York, Free Press. FEATHERMAN D.L., JONES F.L. and HAUSER R.M., 1975, "Assumptions of Social Mobility Research in the US: The Case of Occupational Status", Social Science Research, 4-4, p.329-360.

FRIEDMANN J., 1986, "The World City Hypothesis", Development and change, I7-I, p.69-83.

GOODE W.J., 1982 (1964), The Family, $2^{\text {nd }}$ edition, Englewood Cliffs, Prentice-Hall.

GOODMAN L.A., 1985, "The Analysis of Cross-Classified Data Having Ordered and/or Unordered Categories: Association Models, Correlation Models, and Asymmetry Models for Contingency Tables With or Without Missing Entries", The Annals of Statistics, 13-I, p. I0-69.

-, 1996, "A Single General Method for the Analysis of Cross-Classified Data: Reconciliation and Synthesis of Some Methods of Pearson, Yule, and Fisher, and Also Some Methods of Correspondence Analysis and Association Analysis", Journal of the American Statistical Association, 91-433, p.408-428.

GORDON I. and MONASTIRIOTIS V., 2006, "Urban Size, Spatial Segregation and Inequality in Educational Outcomes", Urban Studies, 43-I, p.213-236.

HALL J.R., 1954, "A Comparison of the Degree of Social Endogamy in England and Wales and the U.S.A." in D. V. Glass (ed.), Social Mobility in Britain, London, Routledge, p.344-346.

HAMPLOVÁ D., 2009, "Educational Homogamy Among Married and Unmarried Couples in Europe: Does Context Matter?", Journal of Family Issues, 30-I, p.28-52.

JENKS G. F., 1967, "The Data Model Concept in Statistical Mapping”, International Yearbook of Cartography, 7-I, p.186-190.

KALMIJN M., 199I, "Status Homogamy in the United States", The American Journal of Sociology, 97-2, p. 496-523. 
Tiré à part adressé à Milan Bouchet-Valat

-, 1998, "Intermarriage and Homogamy: Causes, Patterns, Trends", Annual Review of Sociology, 24, p.395-421.

KATRŇÁK T., FUČíK P. and LUIJKX R., 2012, "The Relationship Between Educational Homogamy and Educational Mobility in 29 European Countries", International Sociology, 27-4, p.551-573.

KATRŇÁK T., KREIDL M. and FÓNADOVÁ L., 2006, "Trends in Educational Assortative Mating in Central Europe: the Czech Republic, Slovakia, Poland, and Hungary, 1988-2000", European Sociological Review, 22-3, p.309-322.

KERR C., DUNLOP J.T., HARBISON F.H. and MYERS C.A., 1960, Industrialism Industrial Man, Harvard, Harvard University Press.

LEEUWEN M.H.D. VAN and MAAS I., 2005, "Endogamy and Social Class in History: An Overview", International Review of Social History, 50-SI3, p.I-23.

LIPSET S.M. and ZETTERBERG H.L., 1959, "Social Mobility in Industrial Societies" in S.M Lipset and R. Bendix (eds.), Social Mobility in Industrial Society, Berkeley, University of California Press, p.II-75.

MADORÉ F., 2015, "Approche comparative de la ségrégation socio-spatiale dans les aires urbaines françaises", Annales de géographie, 706, p.653-680.

MARCIŃCZAK S., GENTILE M. and STĘPNIAKM., 20I3, "Paradoxes of (post) socialist segregation: Metropolitan sociospatial divisions under socialism and after in Poland", Urban Geography, 34-3, p.327-352.

MARCIŃCZAK S., MUSTERD S. and STĘPNIAK M., 2012, "Where the Grass is Greener: Social Segregation in Three Major Polish Cities at the Beginning of the $21^{\text {st }}$ Century", European Urban and Regional Studies, 19-4, p.383-403.

MERON M. and AMAR M. (eds.), 2014, Final Report of the European Statistical System Network on the Harmonisation and Implementation of a European Socio-Economic Classification: European Socio-Economic Groups (ESeG), Kirchberg, Eurostat.

MONAGHAN D., 2015, "Income inequality and educational assortative mating: Evidence from the Luxembourg Income Study", Social Science Research, 52, p.253-269.

MORGAN B.S., 1975, "The Segregation of Socio-economic Groups in Urban Areas: a Comparative Analysis", Urban Studies, 12-1, p.47-60. 
Tiré à part adressé à Milan Bouchet-Valat

-, 1981, "A Contribution to the Debate on Homogamy, Propinquity, and Segregation", Journal of Marriage and Family, 43-4, p.909-921.

PEACH C., 1974, "Homogamy, Propinquity and Segregation: A Re-Evaluation", American Sociological Review, 39-5, p.636-64l.

PUUR A., RAHNU L., MASLAUSKAITE A., STANKUNIENE V. and ZAKHAROV S., 2012, "Transformation of Partnership Formation in Eastern Europe: The Legacy of the Past Demographic Divide", Journal of Comparative Family Studies, 43-3, p.389-417.

RAYMO J.M. and XIE Y., 2000, "Temporal and Regional Variation in the Strength of Educational Homogamy", American Sociological Review, 65-5, p.773-781.

REHER D. S., 1998, "Family Ties in Western Europe: Persistent Contrasts", Population and Development Review, 24-2, p.203-234.

RÓBERT P., 2010, "Stratification and Social Mobility" in S. Immerfall and G. Therborn (eds.), Handbook of European Societies: Social Transformation in the 2 Ist $^{\text {st }}$ entury, Berlin-New York, Springer, p.499-536.

ROYUELA V., VENERI P. and RAMOS R., 20I4, "Income Inequality, Urban Size and Economic Growth in OECD Regions", OECD Regional Development Working Papers, 2014/I0, Paris, OECD.

SASSEN S., 1991, The Global City: New York, London, Tokyo, Princeton, Princeton UP.

SCHNEIDER S.L., 2009, Confusing credentials: the cross-nationally comparable measurement of educational attainment, Ph.D. Thesis, Oxford, University of Oxford.

- and KOGAN I., 2008, "The International Standard Classification of Education 1997: challenges in the application to national data and the implementation in cross-national surveys" in S.L. Schneider (ed.), The International Standard Classification of Education. An Evaluation of Content and Criterion Validity for 15 European Countries, Mannheim, MZES, p. 13-46.

SCHWARTZ C.R., 2013, "Trends and Variation in Assortative Mating: Causes and Consequences", Annual Review of Sociology, 39-I, p.45I-470.

SIMMEL G., 1950 (1903), "The Metropolis and Mental Life" in Id., The Sociology of Georg Simmel, New York, The Free Press, p.409-424.

-, 197I (1908), "Group Expansion and the Development of Individuality" in Id., On Individuality and Social Forms, Chicago, The University of Chicago Press, p.25I-293. 
Tiré à part adressé à Milan Bouchet-Valat

-, 1964 (1908), "The Web of Group Affiliations" in Id., Conflict And The Web Of Group Affiliations, New York, The Free Press, p.128-195.

SMITS J., 2003, "Social Closure Among the Higher Educated: Trends in Educational Homogamy in 55 Countries", Social Science Research, 32-2, p. 25I-277.

- and PARK H., 2009, "Five Decades of Educational Assortative Mating in 10 East Asian Societies", Social Forces, 88-I, p.222-255.

SMITS J., ULTEE W. and LAMMERS J., 1998, "Educational Homogamy in 65 Countries: An Explanation of Differences in Openness Using CountryLevel Explanatory Variables", American Sociological Review, 63-2, p.264-285.

-, 1999, "Occupational Homogamy in Eight Countries of the European Union, 1975-89", Acta Sociologica, 42-I, p.55-68.

-, 2000, "More or Less Educational Homogamy? A Test of Different Versions of Modernization Theory Using Cross-Temporal Evidence for 60 Countries", American Sociological Review, 65-5, p.781-788.

SOBOTKA T. and TOULEMON L., 2008, "Changing Family and Partnership Behaviour: Common Trends and Persistent Diversity Across Europe", Demographic Research, 19, p.85-138.

SOROKIN P., 1998 (1927), Social Mobility, London, Routledge.

SÝKORA L., 2009, "New Socio-Spatial Formations: Places of Residential Segregation and Separation in Czechia", Tijdschrift voor economische en sociale geografie, 100-4, p.417-435.

THORNTON A., 200I, "The Developmental Paradigm, Reading History Sideways, and Family Change", Demography, 38-4, p.449-465.

TORCHE F., 2010, "Educational assortative mating and economic inequality: A comparative analysis of three Latin American countries", Demography, 47-2, p.481-502.

TREIMAN D.J., 1970, "Industrialization and Social Stratification”, Sociological Inquiry, 40-2, p.207-234.

ULTEE W. and LUIJKX R., 1990, “Educational Heterogamy and Father-to-Son Occupational Mobility in 23 Industrial Nations: General Societal Openness or Compensatory Strategies of Reproduction?", European Sociological Review, 6-2, p. $125-149$. 